\title{
Tensions grow over access to DNA bank
}

[PARIS] A debate about the commercial use of DNA banks seems about to erupt in France following controversy about a deal giving the French biotechnology company Genset access to the 'Chronos' DNA bank. The bank contains samples of DNA taken from centenarians and was built up for research into longevity at the Jean Dausset Foundation-Centre d'Etudes du Polymorphisme Humain (CEPH), a non-profitmaking organization based in Paris.

The controversy has been triggered by the dismissal in November of François Schächter, a geneticist at CEPH who worked on the bank's creation in 1991 and its subsequent development. A CEPH spokesperson said there had been a loss of confidence between Schächter and the management, and alleged that Schächter had not respected the terms of confidentiality stipulated in the contract with Genset.

But Schächter, who plans to challenge his dismissal in an industrial tribunal, is expected to argue that his sacking stemmed from his opposition to the Genset deal and the way in which confidentiality clauses in the agreement hampered his collaboration with groups elsewhere, and that his eviction from CEPH denied him access to his research materials.

Under a contract agreed between $\mathrm{CEPH}$ and Genset in 1996, the company has a first right of refusal on results from CEPH's research into ageing, including the Chronos bank, for three years, in return for funding of $\mathrm{CEPH}$ and the ageing programme in particular of FFr32 million (US\$5.3 million). The contract requires CEPH to make Genset an offer before ceding any DNA collections associated with the programme to a third party.

The contract also forbids the passing of any information about research into ageing to a third party — including oral presentation at conferences - without Genset's authorization. Internal CEPH rules forbid staff to divulge "any" form of information without authorization from management.

Gilles Thomas, who was appointed scientific director of CEPH in 1996, says the sacking was unavoidable, alleging that Schächter refused to cooperate with management and infringed confidentiality requirements. Thomas also denies that the management inhibited collaboration, claiming the decline in output from Schächter's laboratory was the result of poor productivity.

CEPH was previously involved in controversy about its DNA banks in 1994, when Philippe Froguel, than a CEPH researcher, successfully challenged plans by $\mathrm{CEPH}$ to give exclusive access to a DNA bank constructed by his group for diabetes research to Millennium, a US biotechnology company (see Nature 368, 175; 1994).

A panel set up by the French government

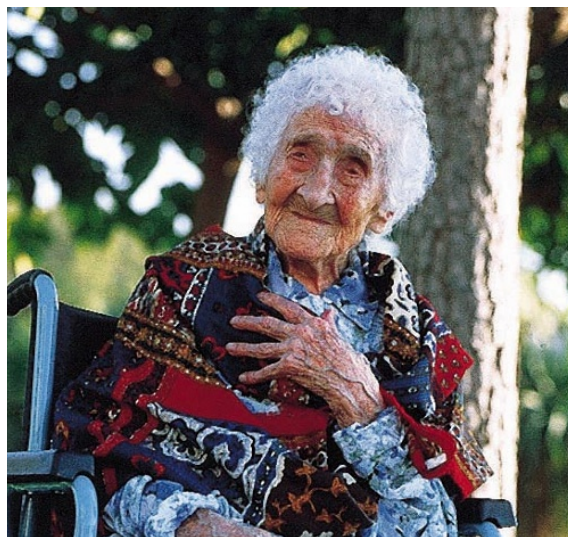

Ageing genes: until her death last year aged 122, Jeanne Calmant was the world's oldest woman.

then recommended that bodies that paid for the DNA bank should have the right to open it to a third party. But it added that the researchers who built the bank also deserved rights, and should have a period in which to exploit the bank themselves (see Nature 370, 4 ; 1994). It also said that donors must agree to any use of such DNA - in particular to commercial applications - and that international agreements were needed to ensure open access to all DNA sequence databases.

But Axel Kahn, a member of the panel, points out that its recommendations were not translated into law, as originally intended. The conditions under which Schächter was ousted from CEPH "run against" the spirit of the recommendations in that it is "obvious" that the scientist has a right to exploit the bank, says Kahn. He is also critical of what he describes as the lack of openness surrounding the negotiation of the CEPH-Genset contract. "A moral engagement was made with the people sampled, which demands that they be informed of the commercial exploitation of their genes," he says.

Michel Allard, scientific and medical director of the IPSEN Foundation, a Parisbased body that helped to organize the campaign to persuade centenarians to contribute their DNA to Chronos, says he now feels "betrayed". "We never told the centenarians that their genes might be patented," he says. "I am not against a contract with a third party, but it should have been done in an open way," says Allard, who also protests that IPSEN was not involved in CEPH's discussions with Genset over the bank.

The contract between CEPH and Genset requires both parties to respect the recommendations of the Louisot report. Thomas disputes Schächter's rights to access the bank, claiming that he was only one of several researchers involved in creating the bank, not the principal instigator. But Allard and others contest this, arguing that Schächter was the driving force behind its creation.
Thomas says that CEPH is willing to discuss giving Schächter access to the bank "if Genset wants to [discuss a collaboration]".

Schächter, who was the first author of one of the first papers showing evidence of differences between centenarians and the rest of the population in the frequency of alleles involved in some age-related diseases (see Nature Genetics 6, 29; 1994), has received backing from many colleagues.

In November 11 national coordinators of an EU network on "'molecular gerontology" wrote to Jean Dausset, the president of $\mathrm{CEPH}$, protesting that the deal with Genset had “seriously hindered" Schächter's participation in the network, and that it had "a serious negative impact on the progress of the EU Biomed-funded initiative".

They add that, while appreciating the need to protect sensitive commercial information, "in this instance, a basic principle of our scientific community, freedom of research seems to have been compromised".

"We have missed the input of Schächter," says Tom Kirkwood, director of the biological gerontology group at the University of Manchester, one of the signatories of the letter. He describes Schächter as a "very talented and imaginative young scientist" and the creation of the Chronos bank as "groundbreaking". It contains DNA samples from hundreds of centenarians, including Jeanne Calmant, who was the world's oldest woman until her death last year at the age of 122 .

Similar banks have since been established worldwide, says Kirkwood, adding that "France took a lead in longevity research, but

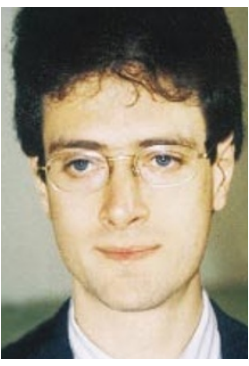

Schächter: sacking started debate. the country's reputation is now being damaged". But Thomas dismisses such protests, alleging they are based on Schächter's account of events, and that he solicited some directly. He also denies that the rules on confidentiality inhibited collaboration. Schächter last week declined to comment publicly on the grounds that litigation is in progress. Genset officials were unavailable for comment.

In a separate development, $\mathrm{CEPH}$ is embroiled in a legal dispute with Genset about what it claims is the latter's refusal to pay instalments of the FFr32 million to $\mathrm{CEPH}$ as agreed in the contract.

Thomas declines to comment on the reasons for Genset's refusal on the grounds that legal proceedings are under way. But he denies that CEPH has reduced its own funding for research into ageing, which would have infringed the contract.

DeclanButler 